\title{
Corruption and Its Handling Strategy in Indonesia
}

\author{
Dwi Antoro $^{1 *}$, I Nyoman Nurjaya ${ }^{2}$, Ismail Navianto ${ }^{3}$, Abdul Madjid $^{4}$ \\ 1. PhD. Candidate at Faculty of Law, Brawijaya University, Indonesia \\ 2. Professor at Faculty of Law, Brawijaya University, Indonesia \\ 3. Lecturer at Faculty of Law, Brawijaya University, Indonesia \\ 4. Lecturer at Faculty of Law, Brawijaya University, Indonesia
}

\begin{abstract}
The law enforcement policy to eradicate corruption is one of the most important factors in the effort to achieve effective resolution of the problem of corruption that has spread to various sectors of life as a nation and state and occurs at various levels of the community to the village. The purpose of this research is to find out the meaning of corruption and investigation of corruption, law enforcement agencies authorized to investigate corruption and how to eradicate corruption in Indonesia. This research uses normative legal research methods with various approaches, including the legislative approach, historical approach and concept approach. This study uses analytical techniques with deductive logic that is processing legal materials deductively namely explaining the general and drawing it to a specific conclusion. The results showed that corruption is a special crime whose handling is extraordinary (extra ordinary). Law enforcement agencies authorized to investigate criminal acts of corruption include, the Republic of Indonesia Police Investigator, Investigating Prosecutors, and Corruption Eradication Commission Investigators. In the process of enforcing criminal acts of corruption, there are at least two important methods to be carried out namely prevention and enforcement methods (Tapping is an effective and effective strategy to trace the role of the perpetrators of corruption which will later be used as evidence in the trial).
\end{abstract}

Keywords: Corruption, Investigation, eradication of corruption, wiretapping.

DOI: $10.7176 / J L P G / 92-25$

Publication date: December $31^{\text {st }} 2019$

\section{A. Introduction}

In the Criminal Justice System, the role of law enforcement officials especially investigators is very important. Because investigators are the foremost in starting the search for material truth through the investigation process. What evidence obtained by the investigator becomes the deciding factor in the continuation of the handling of the corruption case that is handled, so that it is feasible to submit it to the public prosecutor and to be subsequently submitted to the court to be proven before the trial.

From the Corruption Perception Index data released by Transparency International, there is Corruption Perception Index data that gives a value (score 1 to 100) and ranks countries in the world including Indonesia, with data for Indonesia from 2015 to the year. 2018 as follows:

Table 1. Index Transparency International Indonesia

\begin{tabular}{ccccc}
\hline No & Country & Year & Score & Ranking \\
\hline 1 & Indonesia & 2015 & 36 & $88 / 163$ \\
2 & Indonesia & 2016 & 37 & $90 / 176$ \\
3 & Indonesia & 2017 & 37 & $96 / 180$ \\
4 & Indonesia & 2018 & 38 & $89 / 180$ \\
\hline
\end{tabular}

Source: Tranparency International/transparency.org (March 2019)

Based on the table presented above, there have been changes related to Indonesia's score and ranking in the corruption perception index from 2015 to 2018. There was an increase in scores from 2015 to 2018 , but from the rankings there were increases and decreases from the year to year. Seeing this 
condition, it needs special attention and policy in handling corruption in Indonesia. The law enforcement policy on eradicating corruption is one of the most important factors in the effort to achieve effective resolution of the problem of corruption that has spread to various sectors of life as a nation and state and occurs at various levels of the community to the village.

As stated by King Dwight $\mathrm{Y}$ in the concept of legalized corruption contained in the Journal of International Affairs which states that: "Governmental corruption differs from other kinds of corruption in at least two ways: 1. it involves the buying and selling of influence or power over public policy in ways that benefit only particular individuals or groups (e.g., families, cronies and clients), and 2. the corrupt behavior is more easily protected behind a facade of legality because of the corrupt official's position and identity (the concept of legalized corruption) ${ }^{1}$."

Which translates as follows: "Corruption that occurs in government and bureaucratic systems is somewhat different from other conventional corruption, this is one interesting element to be observed. There are at least 2 (two) things that can be examined in corruption in the government sector ", 1. involves the buying and selling of influence or power in a policy that only uses certain individuals or groups (such as, family, cronies and clients), 2. Corruption behavior more easily protected behind a legal rule because of the position and position of corrupt officials."

The problem of corruption which is so complex in both its mode and effect, has spurred law enforcement officials to implement law enforcement against corruption with precise strategies. Law enforcement efforts to eradicate corruption by law enforcement officials (APH) need to be implemented as soon as possible and as soon as possible with a strategy for handling criminal acts that require innovation and strategies for extraordinary law enforcement when compared to handling general crime. Based on the preliminary description above, this study was conducted with the aim of finding out the meaning of corruption and investigating corruption, which law enforcement agencies have the authority to investigate corruption and how is the eradication of corruption in Indonesia.

\section{B. Research Method}

This type of research is normative juridical research which is a process to find the rule of law, legal principles and legal doctrines in order to address the legal issues encountered. ${ }^{2}$ The research approach used is the conceptual approach, historical approach and legislation approach. ${ }^{3}$ The legal material of the study consists of primary legal material consisting of laws and regulations relating to this research, Secondary Legal Material which includes, minutes of the session of the House of Representatives of the Republic of Indonesia with the Government of the Republic of Indonesia related to the discussion of the Corruption Act and Laws The new Corruption Eradication Commission and its academic texts (while still in draft law), the results of dissertation research, theses, books and other scientific literature that provide understanding of primary legal materials, such as legal science textbooks, legal journals, legal reports, and print/electronic media, internet materials, and the results of other studies that support this research, and Tertiary Legal Materials include legal and political dictionaries, encyclopedias, empirical data, and others. The technique of searching primary and secondary legal materials is done by studying literature and searching through the internet (internet searching). ${ }^{4}$ The analysis technique in this research is to use analytical techniques with deductive logic that is to process legal material deductively that is to explain general things and draw them to a specific conclusion. ${ }^{5}$

\section{Results and Discussion}

\section{a. The Meaning of Corruption and Corruption Investigation}

Corruption is a crime that violates the social and economic rights of the community as part of human rights. Law No. 31/1999 concerning Eradication of Corruption Crimes that has been amended by Law No. 20/2001, which will then be abbreviated with the Corruption Act, adheres to the concept of state losses in the sense of formal offense. The element "can be" detrimental to the country's finances should be interpreted as detrimental to the state in the sense of direct or indirect. This means, an action or action can

\footnotetext{
${ }^{1}$ King, Dwight Y. “Corruption in Indonesia: A curable cancer?”. Journal of International Affairs. New York: Spring 2000, 53(2): 603-624.

${ }^{2}$ Marzuki, Peter Mahmud. Penelitian Hukum (Jakarta : Kencana Prenada Media, 2011), p.35.

${ }^{3}$ Ibid, p. 138.

${ }^{4}$ Satjipto Rahadjo, Ilmu Hukum, (Bandung: Citra Aditya Bhakti, 2000), p. 255.

${ }^{5}$ Abdlatif and Hasbi Ali. Perihal Kaedah Hukum, (Bandung: Citra Aditya Bakti, 2010), p.9.
} 
be considered detrimental to the country's finances if the action has the potential to cause state losses. The formulation of a criminal act of corruption as contained in Article 2 paragraph (1) as a formal offense, the existence of state financial losses or state economic losses must not have occurred. ${ }^{1}$

In a social sense it seems that the community does indeed associate corruption as embezzlement of money (belonging to the state or office) and accept bribes in relation to their position or occupation, even though from a legal point of view it is not exactly the same. Considering from a legal standpoint there are many conditions/elements that must be met for a behavior to qualify as one of the corrupt acts as formulated in the law. ${ }^{2}$ Husein Alatas put forward the notion of corruption by mentioning a red thread that explores corruption activities, namely the subordination of the public interest under the interests of personal goals which include norms, duties and general welfare, coupled with confidentiality, betrayal and extraordinary stupidity of the consequences. the consequences suffered by the community. According to him, "corruption is the abuse of trust in the inferest of private gain" (misuse of the mandate for personal gain). ${ }^{3}$

David Nelken explained, "According to the literature, corrupt acts can be identified as either breaches of local law, matters disproved of by public opinion, or behavior that has harmful social consequences. ${ }^{4}$ Jacob Svensson explained: "A common definition of public corruption is the misuse of public office for private gain. Misuse, of course, typically involves applying a legal standard. Corruption defined this way would capture, for example, the sale of government property by government officials, kickbacks in public procurement, bribery and embezzlement of government funds. ${ }^{5}$

The word crime is a translation of the Dutch language strafbaafeit, criminal act in English, and actus reus in Latin. In translating the words of the strafbaarfeit there are various kinds of terms used by several scholars and also in various legislation. The definition of other criminal acts, namely a criminal act, is any act that contains elements: the act is prohibited by law (matching the offense formula), has an unlawful nature, and there is no justification reason. ${ }^{6}$

\section{b. Criminal Investigators and Investigations}

Based on Article 1 number 1 of Law No. 8 of 1981 concerning Criminal Procedure Law, Investigators are state police officers of the Republic of Indonesia or certain civil servant officials who are given special authority by law to conduct investigations. According to Article 1 number 2 of Law No. 8 of 1981 concerning Criminal Procedure Law, Investigation is a series of investigative actions in terms of and according to the way stipulated in this law to search for and collect this evidence to make clear about the criminal acts that occurred and to find the suspect. According to the Indonesian General Dictionary, the meaning of the case is:

- $\quad$ Something; affairs (which must be done, etc.); the subject (something talks, problems, disputes, etc.).

- $\quad$ Events (etc.); the incident.

- $\quad$ Acts of violations (crime; disputes, etc.) that have to do with the law or which are tried by the court; dispute; About things; about. ${ }^{7}$

\section{Form of Corruption} as follows: ${ }^{8}$

According to J. Suwarjo there are several forms or types of criminal acts of corruption, which are

a) Illegal types of criminal acts, namely corruption of state money, avoiding taxes and customs, extortion and bribery;

\footnotetext{
${ }^{1}$ Chazawi, Adami. Hukum Pembuktian Tindak Pidana Korupsi di Indonesia UU No. 31 Tahun 1999 diubah dengan UU No. 20 Tahun 2001, First edition, 1st printing. (Bandung : PT. Alumni, 2006), p. 1-2.

${ }^{2}$ Chaerudin, et al. Strategi Pencegahan dan Penegakan Hukum Tindak Pidana Korupsi. (Bandung: Refika Aditama, 2009)), p. 12 .

${ }^{3}$ Evi Hartanti. Tindak Pidana Korupsi. (Jakarta: Sinar Grafika, 2009), p. 23.

${ }^{4}$ Nelken, David. “Anthropology, corruption, and human rights”. Focaal. Brooklyn, 2010, 2(58).

${ }^{5}$ Svensson, Jakob. "Eight Questions about Corruption”. The Journal of Economic Perspectives; Nashville, 2005, 19(3): 19.

${ }^{6}$ Amir Ilyas. Asas-asas Hukum Pidana. (Yogyakarta: Rengkang Education and Pukap Indomenisa, 2012), p. 28.

${ }^{7}$ Department of Education and Culture. Kamus Umum Bahasa Indonesia. (Jakarta: Balai Pustaka, 1986), p. 741.

${ }^{8}$ Ibid, p. 23
} 
b) Illegal types of criminal charges that are difficult to prove, namely commissions in bank credit, project tender commissions, service fees for granting licenses, promotions, levies on travel money, extortion at interception points on roads, ports and so on;

c) Illegal levies of illegitimate levies by regional governments, ie levies imposed without provisions based on local regulations, but only with decree letters;

d) Bribery, which is a ruler offering money or other services to someone or his family for a service for the money giver;

e) Extortion, that is the person holding the power to demand payment of money or other services in exchange for or reciprocity of the facilities provided;

f) Theft, that is, those in power abuse their power and steal people's property, directly or indirectly;

g) Nepotism, that is, the person in power provides power and facilities to his family or relatives, which other people should also be able or entitled to if done fairly.

\section{Legal Subject in Corruption}

The subject of criminal law in Indonesian corruption criminal law is basically a private person as well as general criminal law. This cannot be eliminated, but a body which can be subject to a criminal act of corruption as stipulated in Article 20 jo also stipulates. Article 1 and 3 of Law Number 31 of 1999 concerning Eradication of Corruption. ${ }^{1}$ If the formulation of the criminal act of corruption in paragraph (1) is detailed it consists of the following elements: ${ }^{2}$

a. His actions:

1) Enrich yourself;

2) Enriching others;

3) Enriching a corporation;

b. Against the law: against the law;

c. Which can be detrimental to the country's finances or the country's economy.

Bearing in mind that corruption in Indonesia is systemic and endemic, so it not only harms the country's finances and the country's economy but also violates the economic and social rights of the community at large. 3 As a form of government commitment that has ratified the UN Convention against Corruption and the demand to fight corruption is the enactment of Law No. 31 of 1999 concerning the Eradication of Corruption as already amended in Law No. 20 of 2001 concerning Amendments to Law No. 31 of 1999 concerning Corruption Eradication.

As it is understood that at the level of the law enforcement process borrowing Soerjono Soekanto's framework, one of the factors that also determines its effectiveness is concerning the substance of the law. The legal substance in this matter is the material of Law No.31 of 1999 concerning Eradication of Corruption Crimes jo. Law No. 20 of 2001 concerning amendments to Law No. 31 of 1999 concerning Eradication of Corruption Crimes. The material referred to is Article 2 and Article 3, the contents of which are as follows: "Based on the facts in Articles 2 and 3 of Law No.31 of 1999 jo. Law No. 20 of 2001 concerning Eradication of Corruption, hereinafter referred to as UU-PTPK, the legal issue regarding the Formulation of the Delik Formulation is an important issue to be examined in order to provide a prescription in the context of legal reform". ${ }^{3}$

\section{c. Law Enforcement Agencies Conducting Corruption Crime Investigations}

\section{a. The Police as Corruption Investigators}

Police are all matters relating to the functions and institutions of the police in accordance with statutory regulations. Whereas the Officials of the Republic of Indonesia National Police are members of the Indonesian National Police who, based on the Act, have general police authority. ${ }^{4}$ In relation to the

\footnotetext{
${ }^{1}$ Adami Chazawi, Op.Cit, p. 117

${ }^{2}$ Adami Chazawi, Op.Cit, p. 135

${ }^{3}$ Amiruddi. Korupsi Dalam Pengadaan Barang dan Jasa. (Yogyakarta: Genta Publishing, 2010), p 53.

${ }^{4}$ Indonesia, Law Number 2 of 2002 concerning the National Police of the Republic of Indonesia (State Gazette of the Republic of Indonesia of 2002 Number 2, Supplement to the State Gazette of the Republic of Indonesia Number 4168), Article 1.
} 
Indonesian National Police as an investigator is contained in Law Number 2 of 2002 concerning the Indonesian National Police, and Law Number 8 of 1981 concerning Criminal Procedure Law (KUHAP). Based on Law Number 2 of 2002 Concerning the Indonesian National Police, Article 14 letter g affirms "The Indonesian National Police is tasked with conducting investigations and investigations of all criminal acts in accordance with criminal procedure code and other statutory regulations."

The authority of the Police in criminal proceedings is contained in Article 16 of Law Number 2 of 2002 concerning the Indonesian National Police: ${ }^{2}$

a. Make arrests, detention, search and seizure;

b. Prohibit anyone from leaving or entering the crime scene for the purposes of investigation;

c. Bringing and confronting people with investigators in the course of an investigation;

d. Telling to stop the person who is suspected and questioning and checking personal identification;

e. Examining and confiscating letters;

f. Calling people to be heard and examined as suspects or witnesses;

g. Bring in the experts who are needed in connection with the examination of the case;

h. Holding a termination of the investigation;

i. Submit case files to the public prosecutor;

j. Submit a request directly to the authorized immigration officer at the immigration checkpoint in an urgent or sudden situation to prevent or deter a person suspected of committing a crime;

k. Provide instructions and investigation assistance to civil service investigators and receive the results of investigations of civil service investigators to be submitted to the public prosecutor; and

1. Carry out other actions according to responsible law.

In addition to the aforementioned authority, whether the police investigator is also authorized to conduct wiretapping, although it is not detailed or clearly stated in Law Number 8 of 1981 concerning Criminal Procedure Law or Law Number 2 of 2002 concerning the Indonesian National Police, this is stated in Law Number 31 Year 1999 Concerning Eradication of Corruption, namely in the explanation of Article 26 states that "The authority of the Investigator in this Article includes the authority to conduct wiretapping". So to answer this, an in-depth study of the authority of the police investigator must be carried out as an investigator of all criminal acts.

In terms of wiretapping authority, the police have legislation that regulates a number of criminal acts in which investigations can be carried out intercepting, including acts of terrorism, narcotics, and psychotropics. But what about the criminal act of corruption? This can be answered from the rules related to the drafting of the prevailing laws and regulations in Indonesia as regulated in Act Number 12 of 2011 concerning the Formation of Laws and Regulations. According to Attachment I of Law Number 12 of 2011 concerning the Formation of Regulations and Regulations, the explanation cannot mention more broadly than what is stated in an article contained in the body of legislation, if what is mentioned contains a new norm or extends the norms contained in the article in the body of the legislation, then it cannot be used as a basis. Because basically the explanation only gives an interpretation of the norms contained in an article. The explanation cannot contain a formulation of new norms or expand/narrow/add norms contained in the article in the body of the legislation.

Based on this, the writer can conclude that the explanation of Article 26 of Law Number 31 Year 1999 Concerning Eradication of Corruption Crime which states that "The authority of the Investigator in

${ }^{1} \mathrm{Ibid}$, Article 14 letter g.

${ }^{2}$ Ibid, Article 16. 
this Article includes the authority to conduct wiretapping", cannot be used as a reference as long as Article principal, namely Article 26 does not mention the authority of investigators to conduct wiretapping. This certainly can give an illustration that investigators who are not given special authority to conduct wiretapping explicitly in the article then do not have the authority to conduct wiretapping.

\section{b. Corruption Eradication Commission (KPK) as Investigator of Corruption Crimes}

The Corruption Eradication Commission was formed with Law Number 30 of 2002 dated 27 December 2002 concerning the Corruption Eradication Commission. The formation of this commission is the implementation of Article 43 of Law Number 31 of 1999 concerning Eradication of Corruption. ${ }^{1}$ The Corruption Eradication Commission was formed with the consideration that the eradication of corruption carried out by the main sub-systems namely the Police and the Prosecutors' Office could not be implemented optimally, so it needed to be improved professionally, intensively, and continuously.

In article 3 of Law Number 30 of 2002 concerning the Corruption Eradication Commission stated that "Corruption Eradication Commission is a state institution that in carrying out its duties and authorities is independent and free from the influence of any power."2 The Corruption Eradication Commission has the authority to coordinate and supervise, including conducting investigations, investigations and prosecution of corruption cases. ${ }^{3}$ All authorities related to investigations, investigations and prosecutions regulated in Law Number 8 of 1981 concerning Criminal Procedure Law also apply to investigators, investigators, and public prosecutors in the Corruption Eradication Commission. The authority includes, among others, the authority to arrest, detain, search, seizure, examine documents. ${ }^{4}$ In addition, according to Law Number 30 of 2002 concerning the Corruption Eradication Commission, the provisions referred to in Article 7 paragraph (2) of Law Number 8 of 1981 concerning Criminal Procedure Law do not apply to investigators of criminal acts of corruption. ${ }^{5}$

The Corruption Eradication Commission can also cooperate in investigating, investigating and prosecuting corruption with other state law enforcement agencies. Other state law enforcement agencies in question are the police, prosecutors, courts, and other specialized bodies of foreign countries that handle cases of corruption. The cooperation is carried out in accordance with applicable laws or regulations or based on international agreements that have been recognized by the Government of the Republic of Indonesia. In connection with wiretapping, for this Supervision Institution has a special article which regulates the authority to conduct wiretapping, namely in Article 12 paragraph (1) letter a, the content of the article "In carrying out the tasks of investigation, investigation and prosecution as referred to in article 6 letters c, the Corruption Eradication Commission has the authority to conduct wiretaps and record conversations. ${ }^{6}$

Therefore, with regard to the authority to conduct wiretapping, the Corruption Eradication Commission with Law Number 30 of 2002 concerning the Corruption Eradication Commission shall continue to be given authority in accordance with this Article 12 Paragraph (1) letter a and with addition only to the procedures and conditions tapping. Whereas with the special authority in Article 12 of Law Number 30 Year 2002 concerning the Corruption Eradication Commission, legally the provisions of Article 26 of Law Number 31 of 1999 concerning Eradication of Corruption will no longer affect the legal basis for wiretapping authority by KPK personnel in handling corruption, because the authority stated in Article 12 of Law Number 30 Year 2002 concerning the Corruption Eradication Commission.

\section{c. The Prosecutor as a Corruption Investigator}

In Article 1 point 1 of Law Number 16 Year 2004 concerning the Attorney General's Office of the Republic of Indonesia it is determined that the Prosecutor is a functional official authorized by this law to act as a public prosecutor and executor of court decisions that have obtained legal force and other powers based on the law. invite. The Attorney General's Office of the Republic of Indonesia as a state government institution that carries out state power in the field of prosecution must be free from the influence of any

\footnotetext{
${ }^{1}$ Indonesia, Law Number 31 of 1999, Op.Cit., Article 43.

${ }^{2}$ Indonesia, Law Number 30 of 2002 concerning the Corruption Eradication Commission (State Gazette of the Republic of Indonesia of 2002 Number 137, Supplement to the State Gazette of the Republic of Indonesia Number 4250), Article 3.

${ }^{3}$ Ibid, Article 6 letter c.

${ }^{4} \mathrm{Ibid}$, Article 38 paragraph 1.

${ }^{5} \mathrm{Ibid}$, Article 38 paragraph 1 .

${ }^{6} \mathrm{Ibid}$, Article 12 paragraph (1) letter a.
} 
party's power, which is to be carried out independently regardless of the influence of governmental powers and the influence of other powers. The Attorney General's Office as one of the law enforcement agencies is demanded to be more involved in upholding the rule of law, protecting public interests, upholding human rights, and combating corruption, collusion, and nepotism $(\mathrm{KKN}){ }^{1}$

In Law Number 16 Year 2004 concerning the Attorney General's Office of the Republic of Indonesia Article 30 explains:

(1) In the criminal field, the AGO has the following duties and authorities:

- Prosecute;

- $\quad$ Carry out the determination of judges and court decisions that have permanent legal force;

- Conduct supervision of the implementation of conditional criminal decisions, supervision criminal decisions, and conditional release decisions;

- $\quad$ Carry out investigations on certain criminal acts based on the law;

- Complete a specific case file and for that reason can carry out additional examination before it is submitted to the court which in its implementation is coordinated with the investigator.

(2) In the field of civil and state administration, prosecutors with special powers can act both inside and outside the court for and on behalf of the state or government. ${ }^{2}$

It can be seen in Article 30 letter $d$ above that in addition to being a prosecuting institution, the Prosecutor's Office also has another authority which is to carry out investigations on certain criminal acts. Thus the Prosecutor's Office can be an investigator in certain criminal acts. The authority of the prosecutor's office to carry out certain criminal investigations is intended to accommodate several statutory provisions that give the authority to the prosecutor's office to carry out an investigation, for example in Law Number 26 of 2000 concerning Human Rights Courts and Law Number 31 of 1999 concerning Eradication of Acts Criminal Corruption as amended by Act Number 20 of 2001, and Act Number 30 of 2002 concerning the Corruption Eradication Commission.

Besides Article 91 paragraph (1) of the Criminal Procedure Code regulates the authority of prosecutors (public prosecutors) to take over the minutes of the examination. If there is no authority to conduct an investigation, then the investigation report is taken over, and can be interpreted illegally. ${ }^{3}$ In accordance with Article 284 paragraph (2) of the Criminal Procedure Code which states: "Within two years after this law was enacted, the provisions of this law shall apply to all cases, with the temporary exception of special provisions of criminal procedure as mentioned in certain laws, until there is a change and/or is declared no longer valid."

Whereas regarding its authority in conducting wiretapping, it returns to the contents of Article 26 of Law Number 31 of 1999 concerning Eradication of Corruption Crimes as amended by Law Number 20 of 2001, namely Investigation, prosecution and examination at a court hearing against criminal acts of corruption, carried out based on applicable criminal procedure law, unless otherwise stipulated in this Law, and in the explanation of Article 26 states that "The authority of the Investigator in this Article includes the authority to conduct wiretapping.

\section{d. Corruption Eradication Strategy in Indonesia}

In the process of enforcing the criminal act of corruption, there are at least 2 major methods that are important to do, namely the Prevention Method and the Enforcement Method. Both of these methods are very important in the level of handling the crime of corruption, one another can not be abandoned. If enforcement is carried out, it will be an optimal action to reduce or eliminate corruption, and vice versa, if it is only prevention, then it will not be effective also for the perpetrators of criminal acts of corruption who

\footnotetext{
${ }^{1} \mathrm{Ibid}$, Article 38 paragraph 1.

${ }^{2}$ Indonesia, Law Number 16 of 2004, Op.Cit., Article 30.

${ }^{3}$ Evi Hartanti, Op.Cit., p. 38.

${ }^{4}$ Indonesia, Law Number 8 of 1981, Op.Cit., Article 284 paragraph 2.
} 
have unintentionally committed corrupt acts. Wiretapping is an effective and effective strategy to trace the role of the perpetrators of corruption that will later be used as evidence in the evidentiary trial.

The authority of wiretapping is owned by the Prosecutor which currently only exists in Article 26 of Law Number 31 of 1999 concerning Eradication of Corruption Crimes as amended by Law Number 20 of 2001, which states that "Investigations, prosecutions and hearings in hearings the trial of corruption is carried out based on the applicable criminal procedure law, unless otherwise stipulated in this Law ", and in the explanation of Article 26 states that" The Authority of the Investigator in this Article includes the authority to conduct wiretapping ", it is not sufficient to be the Prosecutor's foundation in conducting wiretapping in conducting investigations of criminal acts of corruption, bearing in mind that there is no clear attribution and delegation/mandate as required in the theory of authority. With the explanation that the authority of wiretapping is only regulated in an explanation of the article, while Law Number 12 of 2011 states that "the explanation cannot be used as a legal basis for making further regulations and may not include a formula containing the norm", and "the formulation of the article explanation for the sake of article does not expand, narrow, or increase understanding of norms that exist in the torso ", and" does not contain the formulation of delegation ". So it can be concluded that the authority of wiretapping by the Prosecutor is currently not clearly regulated in Indonesian laws and regulations, so it needs to be explicitly regulated in a statutory regulation.

Regarding wiretapping by the Prosecutor, it is concluded that the authority of wiretapping by the prosecutors is important to be clearly regulated in Indonesian laws and regulations, bearing in mind that this will later become the legal basis for the Prosecutor's profession in enforcing the rule of law, in particular the enforcement of the eradication of corruption. If the authority of wiretapping by the Prosecutor has been clearly regulated, the researcher believes that the results of wiretapping by the Prosecutor in the investigation process will later become an important evidence supporting evidence of a criminal case, especially corruption, as has been practiced by the Corruption Eradication Commission investigators.

\section{D.Conclusions}

1. Corruption is a special criminal act whose handling is extraordinary (extraordinary). In investigating criminal acts of corruption, it refers to criminal procedural law regulated in the Criminal Procedure Code (KUHAP) as well as other specific laws which regulate the handling of corruption.

2. Law enforcement agencies authorized to conduct investigations include: Indonesian National Police Investigators, Investigating Prosecutors and Corruption Eradication Commission Investigators.

3. In the process of enforcing the criminal act of corruption, there are at least 2 major methods that are important to do, namely the Prevention Method and the Enforcement Method. Wiretapping as one of the enforcement strategies in handling corruption cases, Wiretapping is an effective and effective strategy to trace the role of the perpetrators of corruption that will later be used as evidence in the evidentiary trial.

\section{Reference}

Abdlatif and Hasbi Ali. Perihal Kaedah Hukum, (Bandung: Citra Aditya Bakti, 2010).

Amir Ilyas. Asas-asas Hukum Pidana. (Yogyakarta: Rengkang Education and Pukap Indomenisa, 2012).

Amiruddi. Korupsi Dalam Pengadaan Barang dan Jasa. (Yogyakarta: Genta Publishing, 2010).

Buchari Said, Hukum Pidana Materil. (Bandung: Universitas Pasundan, 2009).

Chazawi, Adami. Hukum Pembuktian Tindak Pidana Korupsi di Indonesia UU No. 31 Tahun 1999 diubah dengan UU No. 20 Tahun 2001, First edition, 1st printing. (Bandung : PT. Alumni, 2006).

Chaerudin, et al. Strategi Pencegahan dan Penegakan Hukum Tindak Pidana Korupsi. (Bandung: Refika Aditama, 2009).

Department of Education and Culture. Kamus Umum Bahasa Indonesia. (Jakarta: Balai Pustaka, 1986).

Evi Hartanti. Tindak Pidana Korupsi. (Jakarta: Sinar Grafika, 2009).

King, Dwight Y. "Corruption in Indonesia: A curable cancer?”. Journal of International Affairs. New York: Spring 2000, 53(2): 603-624. 
Marzuki, Peter Mahmud. Penelitian Hukum. (Jakarta : Kencana Prenada Media, 2011).

Nelken, David. “Anthropology, corruption, and human rights”. Focaal. Brooklyn, 2010, 2(58).

Satjipto Rahadjo. Ilmu Hukum. (Bandung: Citra Aditya Bhakti, 2000).

Svensson, Jakob. "Eight Questions about Corruption”. The Journal of Economic Perspectives; Nashville, 2005, 19(3): 19.

\section{Laws And Regulations}

Indonesia, Law Number 2 of 2002 concerning the National Police of the Republic of Indonesia (State Gazette of the Republic of Indonesia of 2002 Number 2, Supplement to the State Gazette of the Republic of Indonesia Number 4168), Article 1.

Indonesia, Law concerning Amendment to Law R.I Number 31 of 1999 concerning Eradication of Corruption.

Indonesia, Law Number 30 of 2002 concerning the Corruption Eradication Commission (State Gazette of the Republic of Indonesia of 2002 Number 137, Supplement to the State Gazette of the Republic of Indonesia Number 4250), Article 3.

Indonesia, Law Number 16 of 2004 concerning the Attorney General's Office of the Republic of Indonesia.

Indonesia, Law No. 8 of 1981 concerning. Criminal Procedure Law. 